Relations industrielles

Industrial Relations

\title{
A provincial Labour Code
}

\section{Antonio Barrette}

Volume 1, numéro 6, février 1946

URI : https://id.erudit.org/iderudit/1023933ar

DOI : https://doi.org/10.7202/1023933ar

Aller au sommaire du numéro

Éditeur(s)

Département des relations industrielles de l’Université Laval

ISSN

0034-379X (imprimé)

1703-8138 (numérique)

Découvrir la revue

Citer cet article

Barrette, A. (1946). A provincial Labour Code. Relations industrielles / Industrial Relations, 1(6), 4-4. https://doi.org/10.7202/1023933ar

Tous droits réservés @ C Département des relations industrielles de l’Université Laval, 1946
Ce document est protégé par la loi sur le droit d'auteur. L'utilisation des services d'Érudit (y compris la reproduction) est assujettie à sa politique d'utilisation que vous pouvez consulter en ligne.

https://apropos.erudit.org/fr/usagers/politique-dutilisation/ 


\section{A PROVINCIAL LABOUR CODE}

Note. For our readers' information, we quote hereinbelow an extract of the address delivered on the sixteenth of January 1946 by the Honourable Antonio Barrette, Minister of Labour of the Province of Quebec.

Now that we have entered the period of transition and that we must prepare to return to normal conditions, it is important for us to examine the question of a National Labour Code, a question, indeed, which is presently the object of much concern.

Because the war industries have ceased to produce, the Federal Government does no longer have the same reasons for intervening, and everything relating to industrial and labour relations, conciliation and arbitration, collective bargaining and the determination of wage rates must, in future, go back under the exclusive control of the provinces.

It will be evident, upon reference to the British North America Act, that most of the problems involving relations between Capital and Labour fall within the sphere of the Provinces. Section 92, subsections 13, 14 and 15 of the Act lay down the powers of the Provinces in the following terms :

( 92. In each Province the Legislature may exclusively make laws in relation to matters coming within the classes of subjects hereinafter enumerated :

13. - Property and civil rights.

14. - The administration of justice including procedure in civil matters.

15. - The imposition of punishments for enforcing any law of the province within the compass of its jurisdiction. ")

Now, the problem of relations between Capital and Labour gives rise more particularly to questions of a civil nature :

a) the contract for the hiring of help.

b) the apprenticeship contract;

c) the determination, by decree, of minimum wages;

d) the duration of work; e) the conciliation and arbitration of disputes;

$f$ ) the collective labour agreement and the procedure relating to its negotiation.

All these questions come under civil law and, consequently, fall exclusively within the scope of jurisdiction of the Provinces. The Privy Council has handed down judgment to that effect.

In asking the Federal Government to promulgate a National Code for labour relations, one does not, unfortunately, make the necessary distinctions between respective jusrisdictions of the Federal and Provincial authorities, which jurisdictions are defined in the British North America Act and interpreted by the Privy Council, after having formed the subject of a pact between the Provinces.

Promulgation a complete labour relations code is mostly legislating on civil matters.

A labour relations code embodies the principle of the right to organize, and that of free syndical action. It refers to collective labour negotiations, establishes the procedure to be followed in determining wages, working hours and holidays with pay, deals with the formulating of rules governing apprenticeship, and, finally, calls for the establishment of a procedure for the conciliation and arbitration of disputes.

We have every reason to believe that the provincial bodies actually in operation fully meet present needs and are, to a high degree, qualified to satisfy future. requirements, if, whenever necessary, we reorganize them to cope with the situation which it is within our power so to do.

The point in question here is not one of mere pclitics but a matter of social policy involving the autonomy oi the Province as well as its economic, cultural and social future. 